Reproduced from A Time Bomb for Global Trade: Maritime-related Terrorism in an Age of Weapons of Mass Destruction, by Michael Richardson (Singapore: Institute of Southeast Asian Studies, 2004). This version was obtained electronically direct from the publisher on condition that copyright is not infringed. No part of this publication may be reproduced without the prior permission of the Institute of Southeast Asian Studies. Individual articles are available at $<$ http://bookshop.iseas.edu.sg >

\title{
A Time Bomb For Global Trade
}


The Institute of Southeast Asian Studies (ISEAS) was established as an autonomous organization in 1968. It is a regional centre dedicated to the study of socio-political, security and economic trends and developments in Southeast Asia and its wider geostrategic and economic environment.

The Institute's research programmes are the Regional Economic Studies (RES, including ASEAN and APEC), Regional Strategic and Political Studies (RSPS), and Regional Social and Cultural Studies (RSCS).

ISEAS Publications, an established academic press, has issued more than 1,000 books and journals. It is the largest scholarly publisher of research about Southeast Asia from within the region. ISEAS Publications works with many other academic and trade publishers and distributors to disseminate important research and analyses from and about Southeast Asia to the rest of the world. 


\section{A Time Bomb for Global Trade}

Maritime-related Terrorism in an Age of Weapon of Mass Destruction

Michael Richardson

\section{누타도}

INSTITUTE OF SOUTHEAST ASIAN STUDIES

Singapore 
First published in Singapore in 2004 by ISEAS Publications

Institute of Southeast Asian Studies

30 Heng Mui Keng Terrace, Pasir Panjang

Singapore 119614

E-mail: publish@iseas.edu.sg

- Website: bookshop.iseas.edu.sg

All rights reserved. No part of this publication may be reproduced, stored in a retrieval system, or transmitted in any form or by any means, electronic, mechanical, photocopying, recording or otherwise, without the prior permission of the Institute of Southeast Asian Studies.

(c) 2004 Institute of Southeast Asian Studies, Singapore

The responsibility for facts and opinions in this publication rests exclusively with the author and his interpretations do not necessarily reflect the views or the policy of the publisher or its supporters.

ISEAS Library Cataloguing-in-Publication Data

Richardson, Michael.

A time bomb for global trade : maritime-related terrorism in an age of weapons of mass destruction.

1. Terrorism-Economic aspects.

2. International trade- Effect of terrorism on.

3. Shipping-Safety measures.

I. Title.

II. Title: Maritime-related terrorism in an age of weapons of mass destruction

HV6431 R52

2004

ISBN 981-230-246-8 (soft cover)

Typeset by International Typesetters Pte Ltd

Printed in Singapore by Seng Lee Press 